\title{
Polyunsaturated fatty acids production with a solid-state column reactor
}

\author{
Hung-Der Jang ${ }^{a}$, Shang-Shyng Yang ${ }^{\text {b,c,* }}$ \\ ${ }^{a}$ Department of Food Science, Yuanpei University, Hsinchu 300, Taiwan \\ ${ }^{\mathrm{b}}$ Department of Biochemical Science and Technology, National Taiwan University, Taipei 10617, Taiwan \\ ${ }^{\mathrm{c}}$ Institute of Microbiology and Biochemistry, National Taiwan University, Taipei 10617, Taiwan
}

Received 11 September 2007; received in revised form 3 December 2007; accepted 6 December 2007

Available online 29 January 2008

\begin{abstract}
To investigate the potential production of polyunsaturated fatty acids (PUFAs), a solid-state column reactor of rice bran with Mortierella alpina was used. The optimal conditions for PUFAs production were rice bran supplementation with $3.75 \%\left(\mathrm{w} \mathrm{w}^{-1}\right.$ ) nitrogen source at initial moisture content $57 \%$, initial $\mathrm{pH} 6-7$, aeration, and incubation at $20{ }^{\circ} \mathrm{C}$ for 5 days and then at $12{ }^{\circ} \mathrm{C}$ for 7 days. Each gram of substrate carbon yielded $127 \mathrm{mg}$ of total PUFAs, $12 \mathrm{mg}$ of eicosapentaenoic acid (EPA), $6 \mathrm{mg}$ of arachidonic acid (AA), $5 \mathrm{mg}$ of $\alpha$-linolenic acid (ALA), and $117 \mathrm{mg}$ of linoleic acid (LA) after 12 days incubation. Aeration enhanced the productions of AA, EPA, and total PUFAs. Supplementation of the nitrogen source on the fourth day and then a shift to lower temperature on the fifth day increased EPA production.
\end{abstract}

(C) 2007 Elsevier Ltd. All rights reserved.

Keywords: Polyunsaturated fatty acid; Rice bran; Solid-state fermentation; Column reactor; Mortierella alpina

\section{Introduction}

The $\omega-3$ and $\omega-6$ series of polyunsaturated fatty acids have been identified as potential food additives or as pharmaceuticals for their biological activities. The PUFAs could be used in the treatment of heart and circulatory disorders, cancer, or participate in the inflammatory reaction (Willett, 1993; Certik and Shimizu, 1999; Demaison and Moreau, 2002; Gil, 2002; Ratledge, 2004). The major sources of PUFAs include microorganisms, pig liver, adrenal glands, and marine fish oils. Animal sources, however, have the problems of cholesterol and difficulty of removing some objectionable tastes and odors. Therefore, PUFAs produced from microorganisms would be more desirable than those from animal sources for use as food

\footnotetext{
${ }^{*}$ Corresponding author. Address: Department of Biochemical Science and Technology, National Taiwan University, Taipei 10617, Taiwan. Tel.: +8862 23621519; fax: +886223679827.

E-mail address: ssyang@ntu.edu.tw (S.-S. Yang).
}

additives, supplements, or feedstocks (Cheng et al., 1999). Extensive researches have been carried out on the production of PUFAs by the filamentous fungus Mortierella in submerged culture. Many species of the genus Mortierella have been found to yield exceptionally high amount of PUFAs depending upon the fermentation media and culture conditions (Sajbidor et al., 1990; Bajpai et al., 1991; Jareokitmongkol et al., 1993; Yu et al., 2003; Jang et al., 2005). However, submerged culture required high energy input and produced much wastewater (Yang, 1988).

To be economically competitive, the production of polyunsaturated fatty acids with rice bran should be able to be performed at the rural level. Solid-state fermentation (SSF) can achieve this purpose by reducing the cost of growing microorganisms, high product yields and low wastewater output (Cannel and Moo-Young, 1980; Yang, 1988; Yang and Ling, 1989; Yang and Swei, 1996; Pandey et al., 1999, 2000; Rahardjo et al., 2005). Much published information is available on the production of enzymes of industrial importance, such as amylase, glucoamylase, protease, 
cellulase, ligninase, pectinase and xylanase. and various byproducts have been used successfully in SSF (Pandey et al., 1999, 2000; Haq et al., 2003; Kang et al., 2004; Rahardjo et al., 2005). SSF might provide an alternative for PUFAs production since the association of fungal oil with solid substrate might be used as inexpensive food and feed supplement and fill the marketing claims (Certik and Shimizu, 1999; Jang et al., 2000).

Agricultural wastes such as rice bran, sweet potato residue, and corncob are rich in starchy or cellulosic materials, and thus could be utilized as renewable resources for the growth of microorganisms and the production of metabolites (Yang and Yuan, 1990; Yang and Swei, 1996). In 2005 , the cultivation area of paddy rice was 237,000 ha. and annual production was 2,600,000 tons in Taiwan (Council of Agriculture/Taiwan, 2006). Annual production of rice bran was estimated at 43,160 tons. Rice bran and wheat bran are good substrates for enzyme and oil productions (Deschamps et al., 1985; Yang and Chiu, 1986), and studies on the production of PUFAs using many agricultural wastes have been reported (Jang et al., 2000). However, fewer studies have addressed the factors influencing the fungal growth and lipid formation in large-scale SSF than those with SmF. In the present study, the rice bran was used to produce PUFAs with Mortierella alpina by column reactor, and the optimal conditions for PUFAs production were investigated.

\section{Methods}

\subsection{Solid substrate}

Rice bran was purchased from local market in Taiwan. It contained moisture content $12.4 \pm 1.4 \%$; organic carbon $43.9 \pm 4.5 \%$; total nitrogen $2.1 \pm 0.3 \%$; and carbon/nitrogen ratio 16.4-26.9 (Jang et al., 2000). Rice bran also contained oleic acid (OA) $14.1 \pm 0.6 \mathrm{mg} \mathrm{g}^{-1}$ substrate carbon and LA $12.9 \pm 0.2 \mathrm{mg} \mathrm{g}^{-1}$ substrate carbon, which was equivalent to $40 \%$ and $38 \%$ of the total fatty acids, respectively.

\subsection{Test microbe and culture conditions}

M. alpina ATCC 32222 was purchased from American Type Culture Collection and used for PUFAs production. Mortierella was grown at $20^{\circ} \mathrm{C}$ in a slant containing $\left(\mathrm{g} \mathrm{L}^{-1}\right)$ : glucose, 10; yeast extract, 5; and agar, 20 at $\mathrm{pH}$ $6.5 \pm 0.1$. Mycelia were harvested and then blended with three times the volume of sterilized water in a micro-Waring blender for the preparation of the mycelial suspension. Submerged basal medium comprised of $\left(\mathrm{g} \mathrm{L}^{-1}\right)$ soluble starch, 20; yeast extract, 5; $\mathrm{KNO}_{3}, 10 ; \mathrm{KH}_{2} \mathrm{PO}_{4}, 1$; and $\mathrm{MgSO}_{4} \cdot 7 \mathrm{H}_{2} \mathrm{O}, 0.5$ at $\mathrm{pH} 6.5 \pm 0.1$. The broth was inoculated with $10 \%\left(\mathrm{v} \mathrm{v}^{-1}\right)$ mycelial suspension and shaken at $200 \mathrm{rpm}$ and $25^{\circ} \mathrm{C}$ for $2-9$ days.

The solid substrate comprised (g): rice bran, 1000; yeast extract, $25 ; \mathrm{KNO}_{3}, 50 ; \mathrm{KH}_{2} \mathrm{PO}_{4}, 5$; and $\mathrm{MgSO}_{4} \cdot 7 \mathrm{H}_{2} \mathrm{O}$,
2.5. The sterile medium was mixed thoroughly with $10 \%$ $\left(\mathrm{v} \mathrm{v}^{-1}\right)$ mycelial suspension, the moisture content was adjusted to $57 \%$, and incubated statically at $20^{\circ} \mathrm{C}$ for 5 days and mixed once daily by rotating each flask. The depth of medium in each flask was about $3 \mathrm{~cm}$. The fermentative solid substrates were used for column reactors.

\subsection{Solid substrate fermentation with column reactor}

The column reactors were presterilized by thorough spraying with $70 \%$ alcohol. Ten percent $\left(\mathrm{w} \mathrm{w}^{-1}\right)$ precultured solid substrates were used as inoculum, mixed with $4.5 \mathrm{~kg}$ of sterile rice bran solid substrate medium, and thereafter put into cylindrical column reactors $(60 \mathrm{~cm}$ height $\times 15 \mathrm{~cm}$ i.d., total volume $8.2 \mathrm{~L}$ ) for PUFAs production. The diagram of column reactor and its accessories are shown in Fig. 1. During the fermentative process, the temperature inside internal column reactor was measured with a set of k-type thermocouples at different positions and connected to a temperature detector. The temperatures at 10,20 , and $30 \mathrm{~cm}$ (bottom, middle, and upper layer) far from the bottom, as well as 4.0 and $7.5 \mathrm{~cm}$ (surrounding and central point) far from the outer walls of column reactor were measured and recorded. The filtered air $\left(1.2 \mathrm{~L} \mathrm{~min}^{-1}\right)$ was provided with an air pump and transferred through a perforated acrylic plate beneath the bottom of column reactor. The humidity of the air used was about $76 \%$. Oxygen concentration was measured using a gas sensor connected to an oxygen analyzer. The fermentative substrate of each layer was separately sampled and the moisture content, $\mathrm{pH}$, and PUFAs content were determined periodically. After sampling, the fermentative substrate was mixed thoroughly before being put into the column reactor.

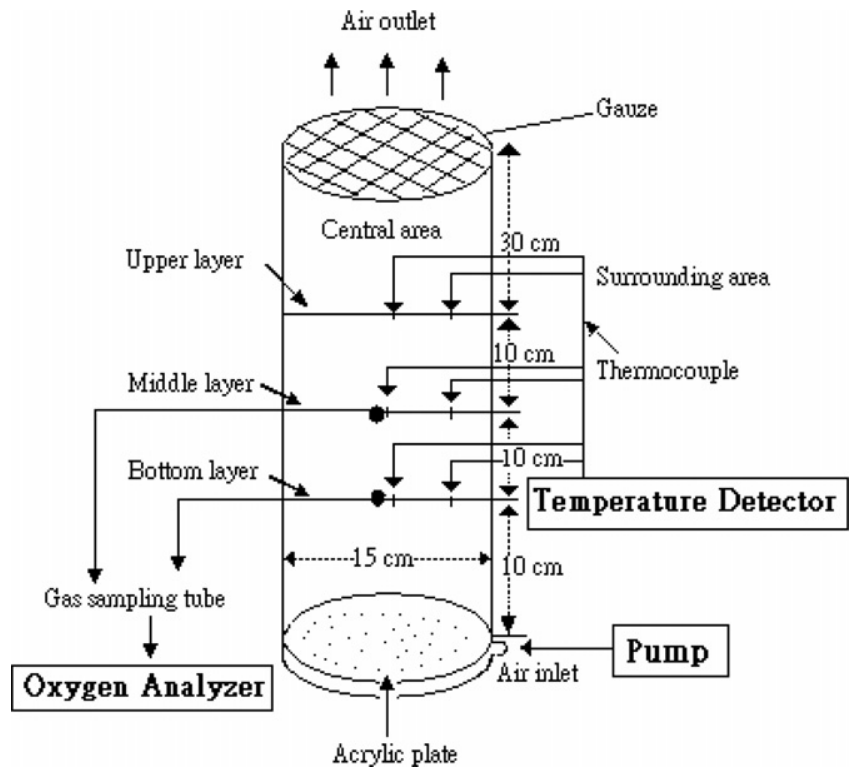

Fig. 1. Diagram of the column reactor and its accessories for solid-state fermentation. 
Column reactor 1 was without aeration and without nitrogen supplementation; column reactor 2 was with aeration but without nitrogen supplement. Both column reactors 1 and 2 were incubated at $20^{\circ} \mathrm{C}$. Column reactor 3 was with aeration and with nitrogen supplement and incubated at $20^{\circ} \mathrm{C}$ for 12 days; column reactor 4 was with aeration and with nitrogen supplement and incubated at $20^{\circ} \mathrm{C}$ for 5 days and then shift to $12{ }^{\circ} \mathrm{C}$ for 3-7 days. The fermentative substrates of column reactors 3 and 4 were supplemented with a mixture of $3.75 \% \mathrm{KNO}_{3}$ and yeast extract $\left(2: 1, \mathrm{w} \mathrm{w}^{-1}\right)$ on the fourth day. After inoculation, the column reactors were put into an temperature-controlled incubator for PUFAs production.

\subsection{Fatty acids analysis}

After fermentation, the substrate sample was mixed with 5 times the volume of chloroform/methanol $\left(2: 1, \mathrm{v} \mathrm{v}^{-1}\right)$, and lipids were extracted by ultrasonic transistor for $2 \mathrm{~h}$ and concentrated by rotary evaporation at $50{ }^{\circ} \mathrm{C}$. The residue of extracted lipid was dissolved in $1 \mathrm{~mL}$ of $0.5 \mathrm{M}$ $\mathrm{KOH}-\mathrm{MeOH}$ solution, and methylated by $1 \mathrm{~mL}$ of $14 \%$ $\mathrm{BF}_{3}$ in $\mathrm{MeOH}\left(\mathrm{w} \mathrm{v}^{-1}\right)$. Saturated $\mathrm{NaCl}$ and anhydrous $\mathrm{Na}_{2} \mathrm{SO}_{4}$ were added to the aqueous layer, and the methylated fatty acids were extracted with $n$-hexane. PUFA content was determined using a GC-8A gas chromatography (Shimadzu Co., Japan) equipped with a 5\% diethylene glycol succinate (60/80 mesh) and $1 \% \mathrm{H}_{3} \mathrm{PO}_{4}$ packed glass column $(2.0 \mathrm{~m} \times 0.26 \mathrm{~mm}$ i.d. $)$ and a flame ionization detector. Nitrogen was used as a carrier gas. Column temperature was programmed from $160{ }^{\circ} \mathrm{C}$ to $200{ }^{\circ} \mathrm{C}$ with an increasing rate of $4{ }^{\circ} \mathrm{C} \mathrm{min}{ }^{-1}$. Injection port and detector temperatures were maintained at $230^{\circ} \mathrm{C}$. Methyl esters of palmitic acid, palmitoleic acid, stearic acid, oleic acid, linoleic acid, $\alpha$-linolenic acid, $\gamma$-linolenic acid (GLA), arachidonic acid, eicosapentaenoic acid, and docosahexaenoic acid were used as standards. Methyl pentadecanoate was added as an internal standard (Jang et al., 2000).

The degree of unsaturation of fatty acids was calculated as the sum of concentration $\left(\%, \mathrm{w} \mathrm{w}^{-1}\right)$ of the product times the number of unsaturated double bonds of each fatty acids as follows (Jang et al., 2000):

Degree of unsaturation $=1\left(\mathrm{wt}^{\%} \%\right.$ of monoene $)+2(\mathrm{wt} \%$ of diene $)+3\left(\mathrm{wt}^{\mathrm{t}} \%\right.$ of triene $)+4(\mathrm{wt} \%$ of tetraene $)+5(\mathrm{wt} \%$ of pentaene).

\subsection{Chemical analysis}

Moisture content was measured by drying a sample at $105^{\circ} \mathrm{C}$ for $24 \mathrm{~h}$ to constant mass. $\mathrm{pH}$ of substrate was determined directly by immersing the electrode into substrate. Organic carbon content of the solid substrate was measured by Nelson and Sommers (1982) and total nitrogen was determined by a modified Kjeldahl method (Yang et al., 1991). The biomass of M. alpina was estimated by determining the protein content, which was calculated as 6.25 times the total nitrogen content.

\subsection{Statistical analysis}

Treatments were performed in triplicate, and experimental data were subjected to the analysis of variance and Duncan's multiple range test $(p=0.05)$ using the Statistical Analysis System (SAS Institute, 2002).

\section{Results and discussion}

\subsection{Physical properties and fatty acids production in column reactor without aeration or nitrogen supplementation}

Physical properties and fatty acids production without aeration or nitrogen supplementation are presented in Fig. 2. The temperature at the central area of bottom layer had a maximum value of $43^{\circ} \mathrm{C}$ at day 2 and then gradually decreased to a constant value after 4 days incubation (Fig. 2A). The other parts of reactor 1 also attained the maximal temperatures $\left(28-33{ }^{\circ} \mathrm{C}\right)$ at day 2 , and the temperature profiles had no significant difference among these parts. The oxygen concentration sharply decreased at day 1 , increased at day 4 and day 8 due to the remixing of solid substrate, and gradually declined to $8 \%$ during cultivation. Substrate $\mathrm{pH}$ increased from an initial value of 6.3-7.4 at day 4 and then decreased to 5.3 after 8 days incubation (Fig. 2B). The $\mathrm{pH}$ drop might be due to the accumulation of organic acid during fermentation (Matsushima et al., 1981; Yang and Huang, 1994). Moisture content at the upper layer increased from $57 \%$ to $62 \%$ at day 4 and then gradually decreased; while the moisture content at the middle and bottom layers gradually increased to the maximal value of $61 \%$ at day 12 (Fig. 2C). The increase of moisture content might be because of the production of metabolic water. Same phenomena were also found in protein enrichment, enzyme, antibiotic, and compost productions (Yang, 1988, 1997, 2005; Yang and Ling, 1989; Yang and Huang, 1994; Yang and Yuan, 1990; Yang and Swei, 1996; Yang and Wang, 1996).

Fatty acids contents after inoculation at time zero were $32 \mathrm{mg}$ OA, $39 \mathrm{mg}$ LA, $0.5 \mathrm{mg}$ ALA, $0.2 \mathrm{mg}$ AA, $0.6 \mathrm{mg}$ EPA and $40.3 \mathrm{mg}$ total PUFAs per gram of substrate carbon. During cultivation, the biomass of microbes increased and it had $80.7 \mathrm{mg}$ protein $\mathrm{g}^{-1}$ substrate after 12 days incubation in the column reactor 1 (Table 1). OA content decreased during the fermentation; whereas ALA, AA and EPA were produced after 4 days incubation. It was postulated that the microorganism converted $\mathrm{OA}$ to longer-chained and more highly unsaturated fatty acids such as ALA, AA and EPA. However, LA content did not show significant difference. The degrees of unsaturation increased from 1.6 at the start of incubation to 2.1 at day 12. These results indicated that more longer-chained and more highly unsaturated fatty acids were produced after 12 days cultivation in the rice bran-based substrate. The upper layer had the highest yield due to the temperature profile that was good for microbial growth and PUFAs production, followed by the middle layer, and the bottom 


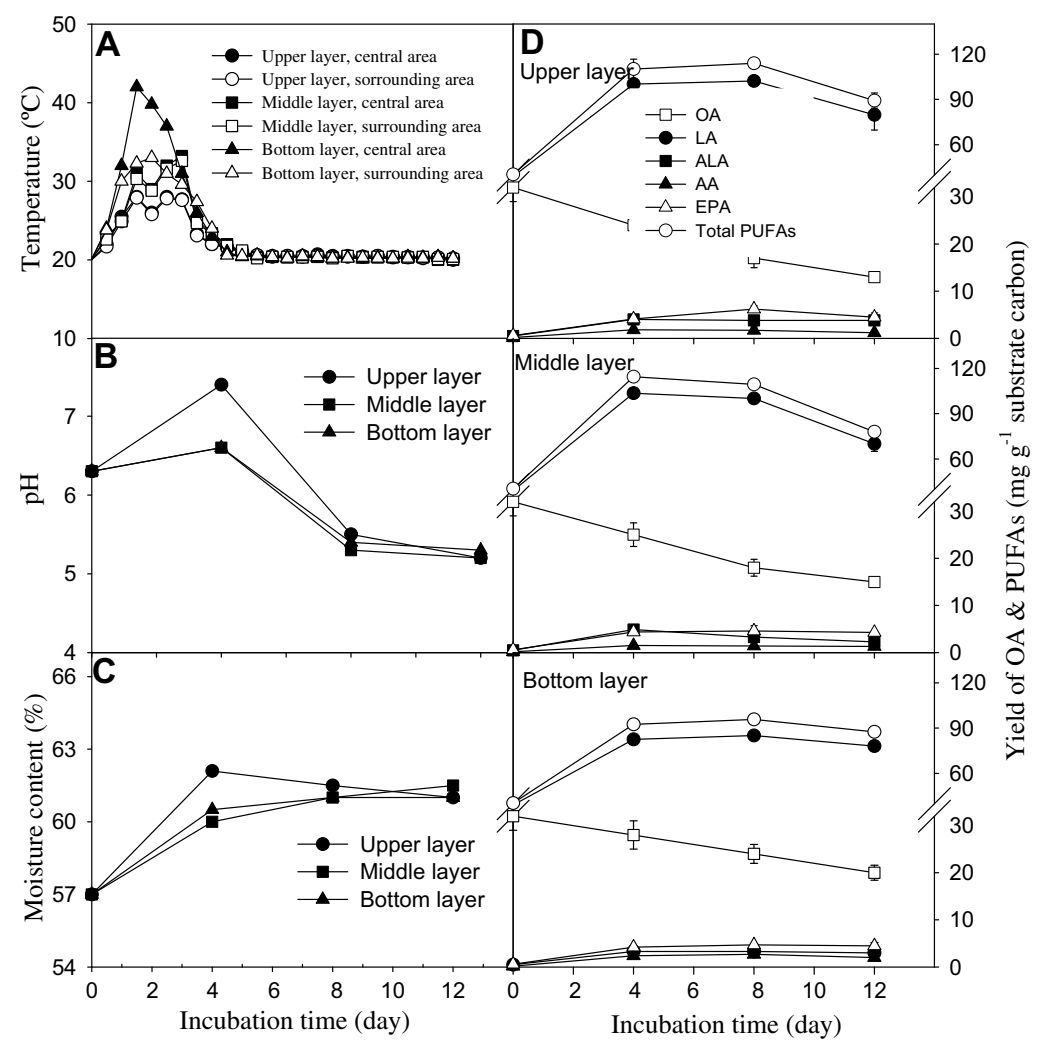

Fig. 2. Physical properties and fatty acids production of column reactors incubated at $20{ }^{\circ} \mathrm{C}$ without aeration and without nitrogen source supplement: (A) temperature, (B) $\mathrm{pH},(\mathrm{C})$ moisture content, and (D) yields of OA and PUFAs. Each value is the mean of triplicate. The standard deviation of the data fell within $5 \%$ of the mean.

layer had the least. The high temperature and the low oxygen concentration at the bottom layer was the limiting factor for microbial growth and PUFAs production. As shown in Fig. 2D, each gram of substrate carbon yielded $6.2 \mathrm{mg}$ of EPA, $1.7 \mathrm{mg}$ of AA, $3.8 \mathrm{mg}$ of ALA, $102.2 \mathrm{mg}$ of LA, $17.0 \mathrm{mg}$ of $\mathrm{OA}$ and $113.9 \mathrm{mg}$ of total PUFAs in the upper layer after 8 days incubation. It was obvious that the contents of ALA, AA and EPA in the fermentative product were comparatively lesser under the cultural condition without aeration or nitrogen supplementation.

\subsection{Physical properties and fatty acids production in column reactor with aeration and without nitrogen supplementation}

Physical properties and fatty acids production with aeration and without nitrogen supplementation are shown in Fig. 3. Temperatures at the central layer and the surrounding area of the bottom layer reached the maximum temperature of $43{ }^{\circ} \mathrm{C}$ and $40^{\circ} \mathrm{C}$ at day 2 , respectively, and then decreased gradually to $20^{\circ} \mathrm{C}$ after 4 days incubation. The temperature decreased from the central area of the middle layer, the surrounding area of middle layer, the central area of the upper layer and the surrounding area of the upper layer. The upper layer and the middle layer had somewhat lower temperature than those of the bottom layer during day 1-3 (Fig. 3A). In general, the temperature profiles had no significant difference between the cultures with and without aeration. The oxygen concentration was about $20 \%$ during the cultivation with aeration of $1.2 \mathrm{~L} \mathrm{~min}^{-1}$. Substrate $\mathrm{pH}$ had the maximal values at day 4 and then decreased to $\mathrm{pH} 5.3$ after 8 days incubation (Fig. 3B). The patterns of substrate $\mathrm{pH}$ change were very similar to those in the non-aeration treatment. The slightly acidic to neutral $\mathrm{pH}$ favored the yield of EPA, AA and PUFAs productions with Mortierella. Same phenomenon was also found in submerged fermentation of algae (Bajpai et al., 1991; Yongmanitchai and Ward, 1991). The moisture content increased from $57 \%$ to the maximal value $64 \%$ in the bottom layer due to the formation of metabolic water by the tested organism (Fig. 3C). Similar phenomena were also observed in the PUFAs production without aeration or nitrogen supplement. However, aeration enhanced the microbial growth, increased the substrate temperature and metabolic water production.

During cultivation, the biomass of microbes increased for the aeration and it had $99.4 \mathrm{mg}$ protein $\mathrm{g}^{-1}$ substrate after 12 days incubation in column reactor 2 (Table 1 ). The biomass of the microbes grown in the column reactor with aeration was significantly higher that those of without aeration. OA and LA contents decreased $10.5-11.6 \%$ for the conversion to longer-chained and more highly unsaturated fatty acids such as ALA, AA and EPA. As a result, the degree of unsaturation also increased from 1.6 at time zero to 2.2 at day 12 . Each gram of substrate carbon 
Table 1

Biomass and fatty acid profiles in the solid-state column reactors

\begin{tabular}{|c|c|c|c|c|c|c|c|c|c|}
\hline \multirow{2}{*}{$\begin{array}{l}\text { Number of } \\
\text { column } \\
\text { reactor }^{\mathrm{a}}\end{array}$} & \multirow{2}{*}{$\begin{array}{l}\text { Sampling } \\
\text { time (day) }\end{array}$} & \multirow{2}{*}{$\begin{array}{l}\text { Biomass } \\
\text { (mg protein } \mathrm{g}^{-1} \\
\text { substrate) }\end{array}$} & \multicolumn{6}{|c|}{ Fatty acids ${ }^{\mathrm{b}}(\%)$} & \multirow{2}{*}{$\begin{array}{l}\text { Degree of } \\
\text { unsaturation }\end{array}$} \\
\hline & & & OA & LA & ALA & AA & EPA & Others & \\
\hline 1 & $\begin{array}{l}0 \\
4 \\
8 \\
12\end{array}$ & $\begin{array}{l}36.5 \pm 1.5^{\mathrm{G}} \\
52.4 \pm 2.5^{\mathrm{F}} \\
71.8 \pm 3.0^{\mathrm{E}} \\
80.7 \pm 2.7^{\mathrm{D}}\end{array}$ & $\begin{array}{l}40.1 \pm 1.5^{\mathrm{A}} \\
38.6 \pm 1.3^{\mathrm{A}} \\
35.0 \pm 1.7^{\mathrm{B}} \\
32.5 \pm 1.0^{\mathrm{C}}\end{array}$ & $\begin{array}{l}38.2 \pm 1.5^{\mathrm{A}} \\
37.4 \pm 1.7^{\mathrm{A}} \\
36.8 \pm 1.3^{\mathrm{A}} \\
37.6 \pm 1.5^{\mathrm{A}}\end{array}$ & $\begin{array}{l}\text { nd } \\
0.3 \pm 0.1^{\mathrm{F}} \\
0.4 \pm 0.1^{\mathrm{F}} \\
0.3 \pm 0.1^{\mathrm{F}}\end{array}$ & $\begin{array}{l}\text { nd } \\
\begin{aligned} 3.8 \pm 0.3^{\mathrm{E}} \\
4.5 \pm 0.3^{\mathrm{D}} \\
4.4 \pm 0.3^{\mathrm{D}}\end{aligned}\end{array}$ & $\begin{array}{l}\text { nd } \\
1.5 \pm 0.1^{\mathrm{F}} \\
1.4 \pm 0.1^{\mathrm{F}} \\
1.5 \pm 0.1^{\mathrm{F}}\end{array}$ & $\begin{array}{l}21.7 \pm 0.9^{\mathrm{AB}} \\
18.4 \pm 0.7^{\mathrm{B}} \\
21.9 \pm 0.9^{\mathrm{AB}} \\
23.7 \pm 0.9^{\mathrm{A}}\end{array}$ & $\begin{array}{l}1.6 \pm 0.1^{\mathrm{D}} \\
2.0 \pm 0.1^{\mathrm{C}} \\
2.1 \pm 0.1^{\mathrm{BC}} \\
2.1 \pm 0.1^{\mathrm{BC}}\end{array}$ \\
\hline 2 & $\begin{array}{l}4 \\
8 \\
12\end{array}$ & $\begin{array}{l}66.5 \pm 3.0^{\mathrm{E}} \\
91.2 \pm 3.5^{\mathrm{C}} \\
99.4 \pm 3.8^{\mathrm{BC}}\end{array}$ & $\begin{array}{l}35.8 \pm 1.3^{\mathrm{B}} \\
30.2 \pm 1.1^{\mathrm{D}} \\
28.5 \pm 1.0^{\mathrm{D}}\end{array}$ & $\begin{array}{l}30.5 \pm 1.7^{\mathrm{B}} \\
26.8 \pm 1.0^{\mathrm{C}} \\
27.7 \pm 1.3^{\mathrm{BC}}\end{array}$ & $\begin{array}{l}1.0 \pm 0.1^{\mathrm{E}} \\
1.3 \pm 0.1^{\mathrm{D}} \\
1.3 \pm 0.1^{\mathrm{D}}\end{array}$ & $\begin{array}{l}10.9 \pm 0.5^{\mathrm{B}} \\
13.2 \pm 0.7^{\mathrm{A}} \\
13.0 \pm 0.7^{\mathrm{A}}\end{array}$ & $\begin{array}{l}5.0 \pm 0.3^{\mathrm{E}} \\
6.2 \pm 0.3^{\mathrm{D}} \\
5.7 \pm 0.3^{\mathrm{D}}\end{array}$ & $\begin{array}{l}16.8 \pm 0.5^{\mathrm{C}} \\
21.9 \pm 0.7^{\mathrm{AB}} \\
23.8 \pm 0.9^{\mathrm{A}}\end{array}$ & $\begin{array}{l}2.0 \pm 0.1^{\mathrm{C}} \\
2.1 \pm 0.1^{\mathrm{BC}} \\
2.2 \pm 0.1^{\mathrm{B}}\end{array}$ \\
\hline 3 & $\begin{array}{l}4 \\
8 \\
12\end{array}$ & $\begin{array}{c}76.8 \pm 3.5^{\mathrm{DE}} \\
107.3 \pm 4.2^{\mathrm{A}} \\
115.2 \pm 5.2^{\mathrm{A}}\end{array}$ & $\begin{array}{l}32.1 \pm 1.3^{\mathrm{C}} \\
28.3 \pm 1.0^{\mathrm{D}} \\
26.6 \pm 0.7^{\mathrm{E}}\end{array}$ & $\begin{array}{l}30.8 \pm 1.5^{\mathrm{B}} \\
21.1 \pm 1.0^{\mathrm{D}} \\
22.0 \pm 0.5^{\mathrm{D}}\end{array}$ & $\begin{array}{l}1.9 \pm 0.2^{\mathrm{BC}} \\
1.5 \pm 0.1^{\mathrm{C}} \\
1.7 \pm 0.1^{\mathrm{C}}\end{array}$ & $\begin{array}{r}9.9 \pm 0.5^{\mathrm{C}} \\
12.9 \pm 0.9^{\mathrm{A}} \\
13.2 \pm 0.9^{\mathrm{A}}\end{array}$ & $\begin{array}{l}10.0 \pm 0.7^{\mathrm{C}} \\
14.2 \pm 0.7^{\mathrm{B}} \\
14.4 \pm 0.9^{\mathrm{B}}\end{array}$ & $\begin{array}{l}15.3 \pm 0.5^{\mathrm{C}} \\
22.0 \pm 0.9^{\mathrm{A}} \\
22.1 \pm 0.7^{\mathrm{A}}\end{array}$ & $\begin{array}{l}2.1 \pm 0.1^{\mathrm{BC}} \\
2.2 \pm 0.1^{\mathrm{B}} \\
2.3 \pm 0.0^{\mathrm{A}}\end{array}$ \\
\hline 4 & $\begin{array}{l}4 \\
8 \\
12\end{array}$ & $\begin{array}{r}74.3 \pm 3.0^{\mathrm{E}} \\
93.5 \pm 3.8^{\mathrm{C}} \\
105.6 \pm 4.2^{\mathrm{B}}\end{array}$ & $\begin{array}{l}33.5 \pm 1.0^{\mathrm{C}} \\
27.5 \pm 0.9^{\mathrm{D}} \\
25.3 \pm 0.7^{\mathrm{E}}\end{array}$ & $\begin{array}{l}30.4 \pm 0.7^{\mathrm{B}} \\
21.4 \pm 0.7^{\mathrm{D}} \\
22.1 \pm 0.5^{\mathrm{D}}\end{array}$ & $\begin{array}{l}2.0 \pm 0.1^{\mathrm{B}} \\
2.8 \pm 0.1^{\mathrm{A}} \\
2.7 \pm 0.3^{\mathrm{A}}\end{array}$ & $\begin{array}{l}8.5 \pm 0.1^{\mathrm{C}} \\
8.7 \pm 0.3^{\mathrm{C}} \\
8.7 \pm 0.5^{\mathrm{C}}\end{array}$ & $\begin{array}{l}10.2 \pm 0.3^{\mathrm{C}} \\
16.6 \pm 0.7^{\mathrm{A}} \\
16.9 \pm 0.7^{\mathrm{A}}\end{array}$ & $\begin{array}{l}16.4 \pm 0.7^{\mathrm{C}} \\
23.0 \pm 0.5^{\mathrm{A}} \\
24.3 \pm 1.0^{\mathrm{A}}\end{array}$ & $\begin{array}{l}2.1 \pm 0.0^{\mathrm{B}} \\
2.2 \pm 0.1^{\mathrm{B}} \\
2.3 \pm 0.0^{\mathrm{A}}\end{array}$ \\
\hline
\end{tabular}

${ }^{\text {a }}$ Column reactor 1 , incubated at $20^{\circ} \mathrm{C}$ without aeration or nitrogen source supplement; column reactor 2 , incubated at $20{ }^{\circ} \mathrm{C}$ with aeration but without nitrogen source supplement; column reactor 3 , incubated at $20^{\circ} \mathrm{C}$ with aeration and nitrogen source supplement; column reactor 4 , incubated at $20{ }^{\circ} \mathrm{C}$ for 5 days and then $12^{\circ} \mathrm{C}$, with aeration and nitrogen source supplement.

${ }^{\mathrm{b}}$ Data are expressed as the average of three determinations \pm standard deviation. Values not sharing the same superscript letters within a column are significantly different by Duncan's multiple range test $(p<0.05)$. nd: not detected; OA: oleic acid; LA: linoleic acid, ALA: $\alpha$-linolenic acid, AA: arachidonic acid; EPA: eicosapentaenoic acid; PUFAs: polyunsaturated fatty acids.

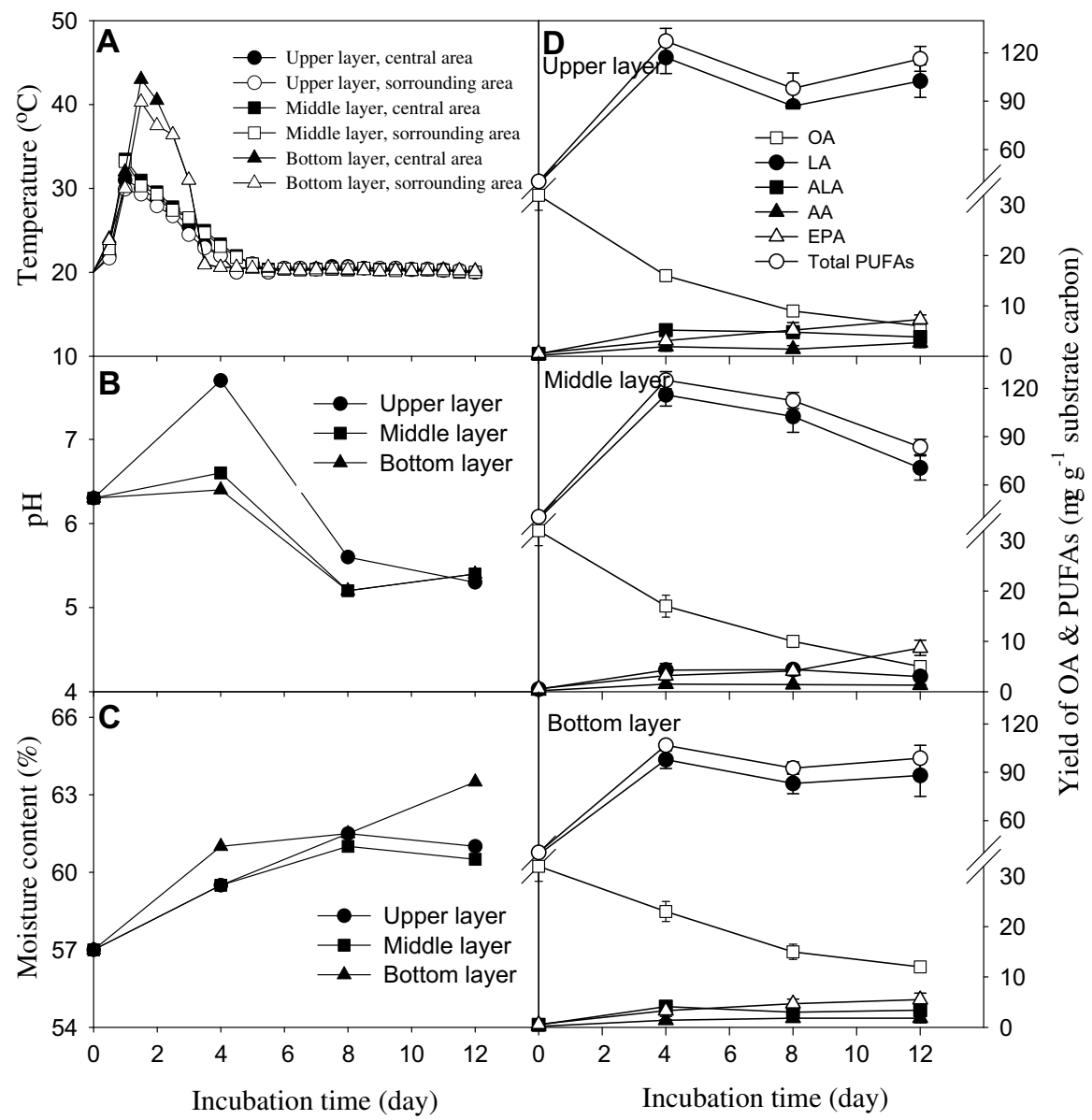

Fig. 3. Physical properties and fatty acids production of column reactors incubated at $20{ }^{\circ} \mathrm{C}$ with aeration but without nitrogen source supplement: (A) temperature, $(\mathrm{B}) \mathrm{pH},(\mathrm{C})$ moisture content, and (D) yields of OA and PUFAs. Each value is the mean of triplicate. The standard deviation of the data fell within $5 \%$ of the mean. 
yielded $7.3 \mathrm{mg}$ of EPA, $3.7 \mathrm{mg}$ of AA, $4.8 \mathrm{mg}$ of ALA, $104.5 \mathrm{mg}$ of LA, $6.1 \mathrm{mg}$ of OA and $120.4 \mathrm{mg}$ of total PUFAs in the upper layer after 12 days incubation (Fig. 3D). The aerobic microbes could grow well in the solid substrate under aeration, which ensured an increasing yield of ALA, AA and EPA. Aeration could increase 13$26 \%$ of PUFAs production and they had significant differences $(p<0.05)$.

\subsection{Physical properties and fatty acids production in column reactor with aeration and nitrogen supplementation}

Physical properties and fatty acids production with aeration and nitrogen supplementation on the fourth day are presented in Fig. 4. The substrate temperature had reached a maximal value $\left(50^{\circ} \mathrm{C}\right)$ at day 1 in all layers, and there was no significant difference among the different layers (Fig. 4A). The oxygen concentration was also about $20 \%$ during the cultivation. The substrate $\mathrm{pH}$ increased from 6.3 to 7.3 in the upper layer at day 4 and then decreased to 5.9 at day 12. Same patterns of $\mathrm{pH}$ change were noted in the other layers, but of lesser magnitude (Fig. 4B). The moisture content increased from $57 \%$ to $64 \%$ at day 4 , and then slightly decreased to $62-63 \%$ after 12 days incuba- tion (Fig. 4C). The pH pattern and moisture content have no significant difference between the cultures with and without nitrogen supplementation. The biomass of the cultures was $115.2 \mathrm{mg}$ protein $\mathrm{g}^{-1}$ substrate after 12 days incubation in column reactor 3 (Table 1). The biomass produced in the column reactor with aeration and nitrogen supplementation was significantly higher than those of column reactors 1 or 2 . Therefore, the results indicated that the cultures could grow better in the solid substrate with aeration and nitrogen supplementation. With the combination of aeration and nitrogen source supplementation, OA and LA contents decreased to $13.5 \%$ and $16.2 \%$ in the total fatty acids, respectively after 12 days incubation; while EPA, AA and ALA contents increased to $14.4 \%, 13.2 \%$ and $1.7 \%$, respectively. The increase of EPA, AA and ALA contents also leads to the increase of the degrees of unsaturation to 2.3 , which were significantly higher than those of column reactors 1 or 2 . Solid substrate fermentation had been carried out in a $500 \mathrm{ml}$ flask, the optimal conditions for PUFAs production were rice bran supplemented with $2.3-5 \%$ nitrogen at an initial of moisture content of $65-68 \%$ and a $\mathrm{pH}$ range of 6-7 (Jang et al., 2000).

PUFAs production per substrate carbon was the highest in the upper layer, followed by the middle layer and the

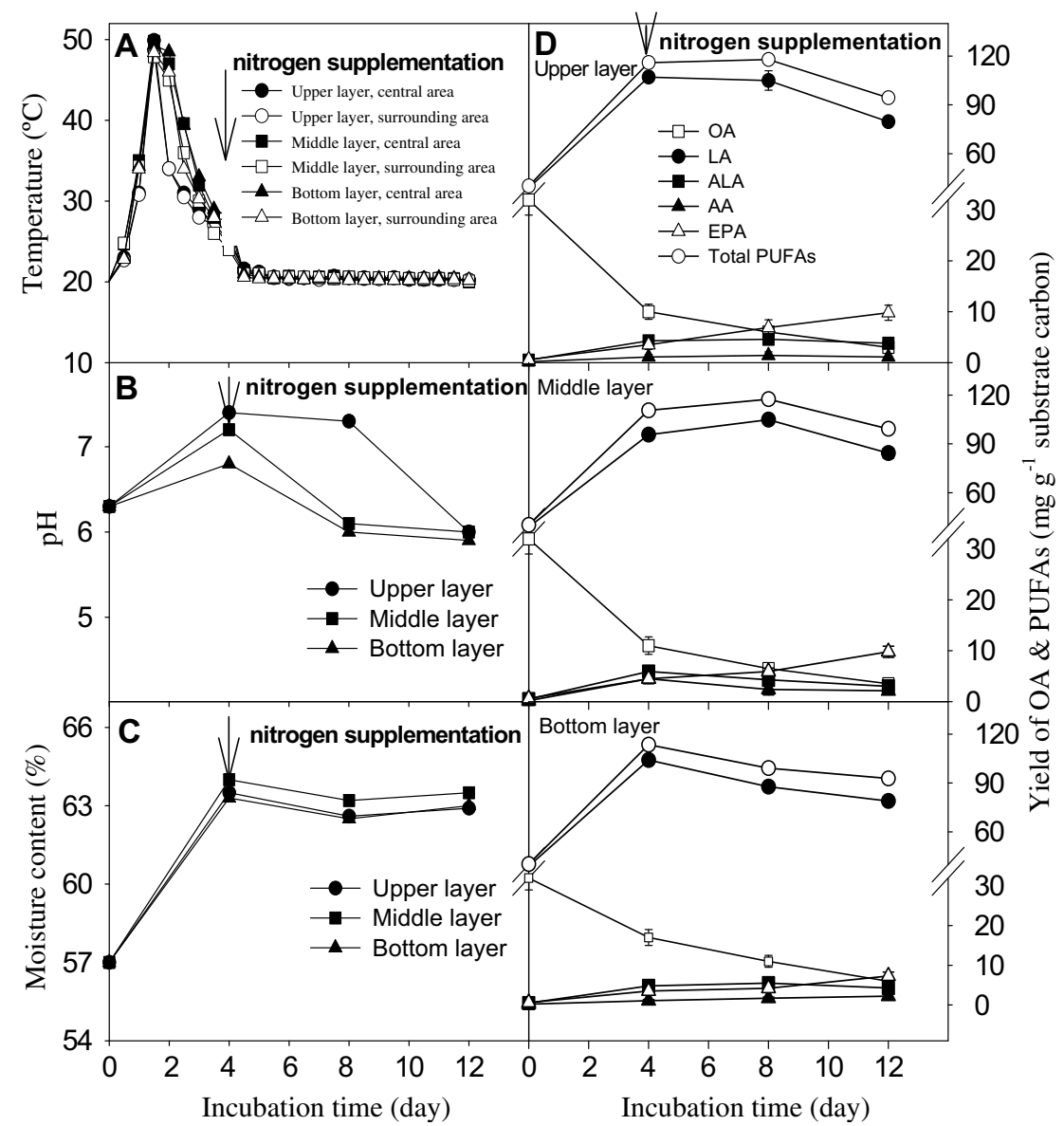

Fig. 4. Physical properties and fatty acids production of column reactors incubated at $20{ }^{\circ} \mathrm{C}$ with aeration and with nitrogen source supplement at fourth day: (A) temperature, (B) pH, (C) moisture content, and (D) yields of OA and PUFAs. Each value is the mean of triplicate. The standard deviation of the data fell within $5 \%$ of the mean. 
bottom layer was the least, especially for EPA and total PUFAs. As shown in Fig. 4D, each gram of substrate carbon yielded $6.9 \mathrm{mg}$ of EPA, $1.4 \mathrm{mg}$ of AA, $4.6 \mathrm{mg}$ of ALA, $105.0 \mathrm{mg}$ of LA, $6.0 \mathrm{mg}$ of $\mathrm{OA}$ and $117.9 \mathrm{mg}$ of total PUFAs in the upper layer for 8 days incubation. In accordance to our previous work, the total nitrogen and carbon/ nitrogen ratio of rice bran used as the solid substrate were $2.1 \pm 0.3 \%$ and 16.4-26.9, respectively (Jang et al., 2000). Nitrogen source supplement could provide additional nutrients for microbial growth and consequently increase PUFAs production. Ben-Amotz et al. (1985) also reported that high concentrations of nitrogen source could stimulate EPA production. The information was evident that nitrogen content of the solid substrate was very important for Mortierella growth, and the cultures with nitrogen source supplement could stimulate $\omega-3$ PUFA production, especially EPA. Sajbidor et al. (1990) and Jang et al. (2005) also indicated that the concentrations of carbon and nitrogen sources and carbon/nitrogen ratio of solid substrate were very important in lipid production. In this study, the supplement of nitrogen source significantly increased the yields of EPA ( $p<0.05)$; however, the yields of total PUFAs were not significantly different.
3.4. Effect of incubation temperature on physical properties and fatty acids production

Effect of incubation temperature on physical properties and fatty acids production is shown in Fig. 5. The temperature increased to a maximal value $47^{\circ} \mathrm{C}$ at day 2 and then decreased gradually. Temperatures in central areas were higher than those of surrounding areas, and the middle and bottom layers were also higher than those in the upper layer. However, when the incubation temperature was shifted to $12{ }^{\circ} \mathrm{C}$ at day 5 , the column reactor temperature decreased rapidly to $12.1-13.5^{\circ} \mathrm{C}$ (Fig. 5A). Oxygen concentration remained at about $20 \%$ due to aeration during fermentation process. Substrate $\mathrm{pH}$ of the upper and middle layers increased slightly to 7.1 at day 4 and then decreased gradually to $\mathrm{pH} 5.3$ (Fig. 5B). The moisture content of the bottom layer increased from $57 \%$ to $65 \%$ at day 4 and then decreased slightly during cultivation; while the moisture contents of the upper and middle layers increased gradually and had the highest at day 8 (Fig. 5C). The biomass $\left(105.6 \mathrm{mg}\right.$ protein $\mathrm{g}^{-1}$ substrate after 12 days cultivation) in column reactor 4 increased rapidly before day 4 and increased gradually after the temperature shift (Table

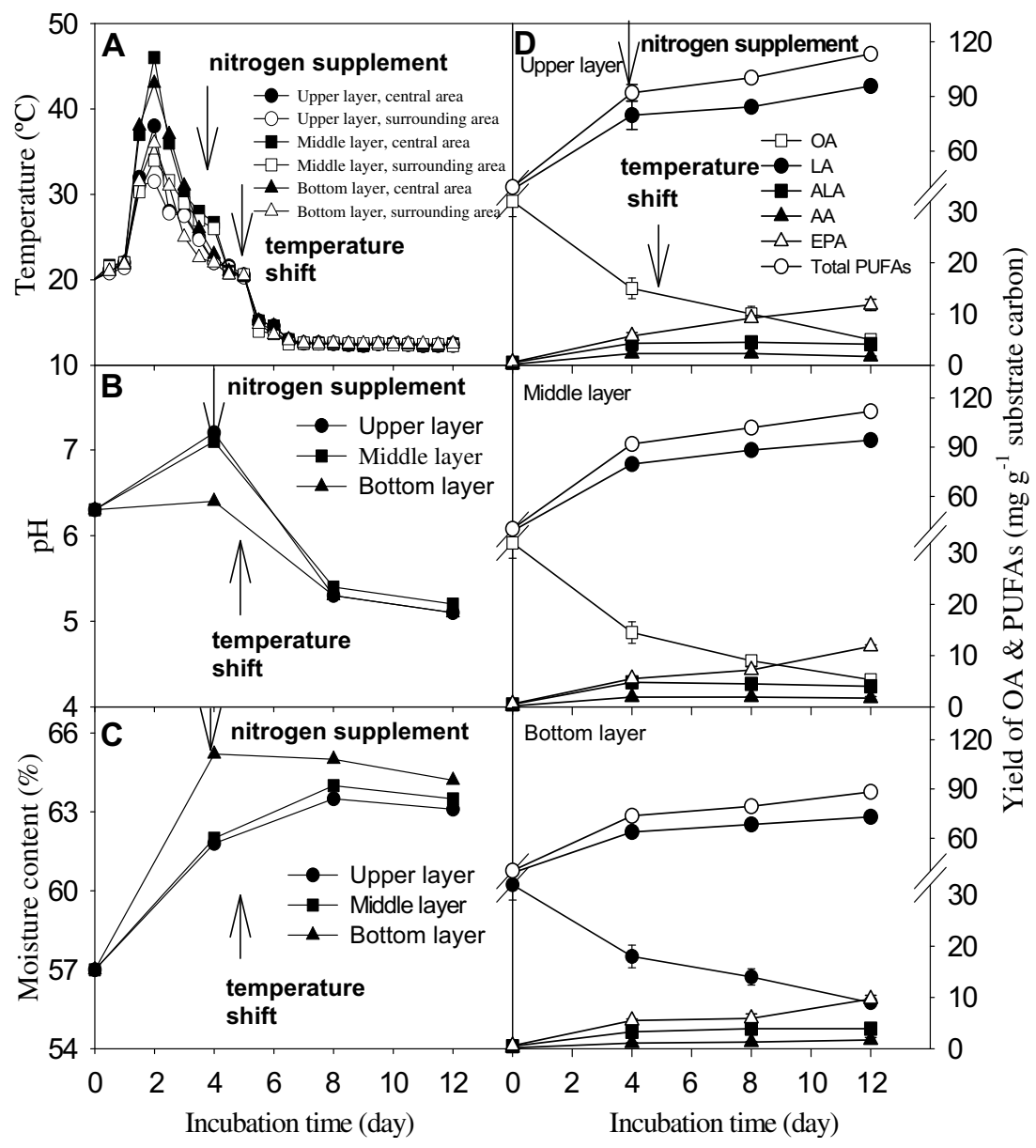

Fig. 5. Physical properties and fatty acids production of column reactors incubated at $20{ }^{\circ} \mathrm{C}$ for 5 days and then shift to $12{ }^{\circ} \mathrm{C}$ with aeration and with nitrogen source supplement at 4th day: (A) temperature, (B) $\mathrm{pH},(\mathrm{C})$ moisture content, and (D) yields of OA and PUFAs. Each value is the mean of triplicate. The standard deviation of the data fell within $5 \%$ of the mean. 
1). The degrees of unsaturation of the final products were 2.3 , which were not significantly different from those of column reactors 3. However, the degrees of unsaturation of the column reactor with temperature shift were higher than those of column reactors 1 or 2 .

PUFAs production of the fungi was significantly influenced by the moisture content of substrate in solid substrate fermentation. Jang et al. (2000) reported that initial moisture content of solid substrate ranging from $60 \%$ to $65 \%$ was good for PUFAs production. Moisture content at $70-75 \%$ favored the production of $\omega-6$ series PUFAs; while moisture content at $60-65 \%$ was good for the production of $\omega-3$ series PUFAs. Zandrazil and Brunert (1981) indicated that low moisture levels reduced the solubility of nutrients and the swelling of substrate and increased the water tension. Correspondingly, high moisture contents decreased the porosity and the gas exchange, induced the loss of particle structure and the production of stickiness, reduced the gas volume, and enhanced the aerial mycelium formation (Lekha and Lonsane, 1994).

The low temperature shift enhanced the concentration of OA and increased the yields of EPA, ALA and total PUFAs, however, AA production was reversed. The yields of EPA at the upper and middle layers were significantly higher than those of the bottom layer $(p<0.05)$. Low temperature cultivation increased the production of $\omega-3$ series PUFAs such as EPA. Each gram of substrate carbon yielded $12.0 \mathrm{mg}$ of EPA, $1.7 \mathrm{mg}$ of AA, $4.1 \mathrm{mg}$ of ALA, $95.7 \mathrm{mg}$ of LA, $5.0 \mathrm{mg}$ of OA and $113.3 \mathrm{mg}$ of total PUFAs in the upper layer for 12 days incubation (Fig. 5D). The yield of EPA increased $24 \%$ higher than that at $20^{\circ} \mathrm{C}$ after incubation for 12 days. EPA and ALA contents were $16.9 \%$ and $2.7 \%$ of total PUFAs, respectively. When the cultivation temperature was shifted to $12^{\circ} \mathrm{C}$ on fifth day. Microbial growth at low temperature increased the degree of unsaturation of fatty acids in membrane, decreased the carbon-chain length of fatty acid, and helped maintain membrane function for optimal metabolism (Toivonen et al., 1992; Terrados and Lopez-Jimenez, 1996).

In summary, PUFAs production of rice bran in column reactor with $M$. alpina is a feasible process. The OA in rice bran can be metabolized and converted to long-chained and highly unsaturated PUFAs, such as AA, EPA and ALA. Aeration, supplementation with nitrogen source, and shift to $12{ }^{\circ} \mathrm{C}$ at late growth stage increased the PUFAs yields. Each gram of substrate carbon yielded $12 \mathrm{mg}$ of EPA, $6 \mathrm{mg}$ of AA, $5 \mathrm{mg}$ of ALA, $117 \mathrm{mg}$ of LA, $9 \mathrm{mg}$ of OA and $127 \mathrm{mg}$ of total PUFAs. PUFAs production with SSF offers advantages over that of SmF. The PUFAs productivity of each gram of substrate carbon was higher in SSF than that in SmF. The cultures in SSF favored the production of a higher content of $\omega-3$ series of PUFAs in total fatty acids than those in SmF. Finally, the product of SSF could be dried and consumed directly without further extraction treatment. Agricultural waste such as rice bran could be used as solid substrates for fermentative production of high-valued products. Therefore,
PUFAs production with solid-state column reactor might be a feasible and economic process in agricultural waste treatment and reutilization.

\section{References}

Bajpai, P.K., Bajpai, P., Ward, O.P., 1991. Production of arachidonic acid by Mortierella alpina ATCC 32222. J. Indust. Microbiol. 8, 179-186.

Ben-Amotz, A., Tornabene, T.G., Thomas, W.H., 1985. Chemical profile of selected species of microalgae with emphasis on lipids. J. Phycol. 21, $72-81$.

Cannel, E., Moo-Young, M., 1980. Solid state fermentation system. Proc. Biochem. 15, 2-7.

Certik, M., Shimizu, S., 1999. Biosynthesis and regulation of microbial polyunsaturated fatty acids production. J. Biosci. Bioeng. 87, 1-14.

Cheng, M.H., Walker, T.H., Hulbert, G.J., Raman, D.R., 1999. Fungal production of eicosapentaenoic acid and arachidonic acids from industrial waste streams and crude soybean oil. Bioresource Technol. 67, 101-110.

Council of Agriculture/Taiwan, 2006. Official Statistic Report 2005. Council of Agriculture, Taipei, Taiwan.

Demaison, L., Moreau, D., 2002. Dietary $\omega-3$ polyunsaturated fatty acids and coronary heart disease-related mortality: a possible mechanism of action. Cell Mol. Life Sci. 59, 463-477.

Deschamps, F., Giuliano, C., Asther, M., Huet, M.C., Roussos, S., 1985. Cellulase production by Trichoderma harzianum in static and mixed solid-state fermentation reactors under nonaseptic conditions. Biotech. Bioeng. 27, 1385-1388.

Gil, A., 2002. Polyunsaturated fatty acids and inflammatory diseases. Biomed. Pharmacother. 56, 388-396.

Haq, I., Ashraf, H., Iqbal, J., Qadeer, M.A., 2003. Production of alpha amylase by Bacillus licheniformis using an economical medium. Bioresource Technol. 87, 57-61.

Jang, H.D., Lin, Y.Y., Yang, S.S., 2000. Polyunsaturated fatty acid production with Mortierella alpina by solid substrate fermentation. Bot. Bull. Acad. Sinica 41, 41-48.

Jang, H.D., Lin, Y.Y., Yang, S.S., 2005. Effect of culture media and conditions on polyunsaturated fatty acids production by Mortierella alpina. Bioresource Technol. 96, 1633-1644.

Jareokitmongkol, S., Shimizu, S., Yamada, H., 1993. Production of an eicosapentaenoic acid-containing oil by a $\Delta 12$ desaturasedefective mutant of Mortierella alpina 1S-4. J. Am. Oil Chem. Soc. 70, 119-123.

Kang, S.W., Park, Y.S., Lee, J.S., Hong, S.I., Kim, S.W., 2004. Production of cellulases and hemicellulases by Aspergillus niger KK2 from lignocellulosic biomass. Bioresource Technol. 91, 153-156.

Lekha, P.K., Lonsane, B.K., 1994. Comparative titres, location and properties of tannin acyl hydrolase produced by Aspergillus niger PKL104 in solid state, liquid surface and submerged fermentation. Process Biochem. 29, 497-503.

Matsushima, K., Hayakawa, M., Ito, M., Stimada, K., 1981. Features of the proteolytic enzyme system of hyper-acid productive and non-acidproductive fungi. J. Gen. Appl. Microbiol. 27, 423-426.

Nelson, D.W., Sommers, L.E., 1982. Total carbon, organic carbon and organic matter. In: Page, A.L. (Ed.), Methods of Soil Analysis, Part 2, Chemical and Microbiological Properties. The American Society of Agronomy, Wisconsin, pp. 539-580.

Pandey, A., Selvakumar, P., Soccol, C.R., Nigam, P., 1999. Solid-state fermentation for the production of industrial enzymes. Curr. Sci. 77, 149-162.

Pandey, A., Soccol, C.R., Mitchell, D.A., 2000. New developments in solid-state fermentation. I. Bioprocesses and products. Process Biochem. 35, 1153-1169.

Rahardjo, Y.S.P., Sie, S., Weber, F.J., Tramper, J., Rinzema, A., 2005. Effect of low oxygen concentrations on growth and $\alpha$-amylase production of Aspergillus oryzae in model solid-state fermentation systems. Biomol. Eng. 21, 163-172. 
Ratledge, C., 2004. Fatty acid biosynthesis in microorganisms being used for single cell oil production. Biochimie 86, 807-815.

Sajbidor, J., Dobronova, S., Certik, M., 1990. Arachidonic acid production by Mortierella sp. S-17: influence of $\mathrm{C} / \mathrm{N}$ ratio. Biotechnol. Lett. $12,455-456$.

SAS Institute, 2002. SAS User's Guide Statistics. SAS Institute Inc., Cary, NC, USA.

Terrados, J., Lopez-Jimenez, J.A., 1996. Fatty acid composition and chilling resistance in green algae Caulerpa prolifera (Forrskal) Lamouroux (Chlorophyta, Caulerpales). Biochem. Mol. Biol. Int. 39, 863-869.

Toivonen, L., Laakso, S., Rosenguist, H., 1992. The effect of temperature on growth, indole alkaloid accumulation and lipid composition of Catharanthus roseus cell suspension cultures. Plant Cell Rep. 11, 390394.

Willett, W.C., 1993. Intake of trans fatty acids and risk of coronary heart disease among women. Lancet 341, 581-585.

Yang, S.S., 1988. Protein enrichment of sweet potato residue with amylolytic yeasts by solid-state fermentation. Biotechnol. Bioeng. 32, 886-890.

Yang, S.S., 1997. Preparation and characterization of compost. J. Biomass Energ. Soc. China 16, 47-62.

Yang, S.S., 2005. Development and application potential of biofertilizers. Agric. Biotechnol. Ind. Quart. 4, 9-17.

Yang, S.S., Chang, H.L., Wei, C.B., Lin, H.C., 1991. Reduce waste production in the Kjeldahl methods. J. Biomass Energ. Soc. China 10, $147-155$.
Yang, S.S., Chiu, W.F., 1986. Protease production with sweet potato residue by solid state fermentation. Chin. J. Microbiol. Immunol. 19, 276-288.

Yang, S.S., Huang, C.I., 1994. Protease production by amylolytic fungi in solid state fermentation. J. Chin. Agric. Chem. Soc. 32, 589-601.

Yang, S.S., Ling, M.Y., 1989. Tetracycline production with sweet potato residue by solid state fermentation. Biotechnol. Bioeng. 33, 1021-1028.

Yang, S.S., Swei, W.J., 1996. Oxytetracycline production by Streptomyces rimosus in solid-state fermentation of corn-cob. World J. Microbiol. Biotechnol. 12, 43-46.

Yang, S.S., Wang, J.Y., 1996. Morphogenesis, ATP content and oxytetracycline production by Streptomyces rimosus in solid substrate cultivation. J. Appl. Bacteriol. 80, 545-550.

Yang, S.S., Yuan, S.S., 1990. Oxytetracycline production by Streptomyces rimosus in solid state fermentation of sweet potato residue. World $\mathbf{J}$. Microbiol. Biotechnol. 6, 236-244.

Yongmanitchai, W., Ward, O.P., 1991. Growth and omega-3 fatty acid production by Phaeodactylum tricornutum under different culture conditions. Appl. Environ. Microbiol. 57, 419-425.

Yu, L.J., Qin, W.M., Lan, W.Z., Zhou, P.P., Zhu, M., 2003. Improved arachidonic acids production from the fungus Mortierella alpina by glutamate supplementation. Bioresource Technol. 88, 265-268.

Zandrazil, F., Brunert, H., 1981. Investigation of physical parameters important for solid-state fermentation of straw by white rot fungi. Eur. J. Appl. Microbiol. Biotechnol. 11, 183-188. 